\title{
Fiscal Shocks, Budgetary Pressures, and Public Education Expenditure Stabilization
}

Peter A. Jones, Vincent Reitano, \& Christian Buerger

Fiscal shocks exert budgetary pressures on school districts and constrain their ability to provide public education. An emerging literature examines the role of fiscal reserves to mitigate expenditure cuts in school districts. In the U.S. context, this article provides evidence that Kentucky school districts from school years 2001-2002 to 2013-2014 drained fiscal reserves and cut expenditures in response to revenue decreases. Further, school districts drained fiscal reserves to stabilize non-instructional expenditures, which have fixed costs. Collectively, the findings presented in this article build evidence that school districts strategically respond to budgetary pressures.

Keywords: budgeting, financial management, fiscal reserves, school districts

This is the author's manuscript of the article published in final edited form as:

Jones, P. A., Reitano, V., \& Buerger, C. (2020). Fiscal Shocks, Budgetary Pressures, and Public Education Expenditure Stabilization. International Journal of Public Administration. https://doi.org/10.1080/01900692.2020.1859531 


\section{Introduction}

The World Bank (2017) recognizes the economic and political challenges that budgetary pressures present for educational administrators around the world. In particular, when faced with "budgetary constraints", the World Bank (2017) recommends that "capital and non-salary, recurring spending" be cut in the short-term and more drastic fiscal measures be considered in the medium-term (p. 5). Even with these critical recommendations, educational researchers acknowledge that "fiscal shocks are largely unexplored" for educational administrators facing budgetary pressures (Nelson and Balu, 2014, pp. 601-602).

In addition to the cutback management strategies recommended by the World Bank (2017), educators can use fiscal reserves to mitigate the impact of fiscal shocks (Arapis, Reitano, and Bruck, 2017; Government Finance Officers Association [GFOA], 2017). Educational administrators can deposit money in these funds when revenues exceed expenditures and withdraw from them when faced with budgetary pressures (e.g., Arapis et al., 2017; Vanyolos, 2011). There are different types of fiscal reserves that educational administrations can draw from. Unassigned fiscal reserves can be drawn down on a discretionary basis while other types of fiscal reserves are saved and restricted for particular purposes (Gorina, Maher, and Park, 2019).

The literature on fiscal reserves focuses mainly on U.S. subnational governments (Gorina et al., 2019), and there is a limited but growing knowledge about how U.S. educational administrators may accumulate and withdraw from their fiscal reserves (Duncombe and Hou, 2014). From the few existing studies, most focus on the accumulation of fiscal reserves, which is also referred to as fiscal slack in the context of U.S. school districts (e.g., Barrett et al., 2019; Duncombe and Hou, 2014). In contrast, 
only one study that finds that U.S. school districts actually drained fiscal reserves to mitigate expenditure cuts during the Great Recession (Arapis et al., 2017).

To build the literature, this article develops a general conceptual framework about how governments deposit money into and withdraw funds from fiscal reserves. This framework is then applied to the literature on U.S. school districts. As the current literature mainly focuses on the accumulation of reserves, this study employs cutback management theory to establish how those accumulated savings are utilized. With this framework, three research questions are addressed. First, do U.S. school districts use unassigned fiscal reserves to stabilize expenditure cuts? Second, do U.S. school districts use other fiscal reserves to stabilize expenditure cuts? Third, do U.S. school districts use either unassigned fiscal reserves or other fiscal reserves to stabilize cuts to particular expenditure categories?

To answer these three research questions, this article uses a panel dataset with fiscal and socioeconomic factors covering all Kentucky school districts $(\mathrm{n}=176)$ from school years 2001-2012 to 2013-2014. The empirical panel model estimates the effect of changes in fiscal reserves on different measures of school district expenditures, while controlling for changes in revenues, prior year spending, and a host of other covariates.

This article advances the literature on the use of fiscal reserves in public education on two fronts. First, it builds a theoretical frameworks that helps explain how governments, including school districts, build and use fiscal reserves. This framework is augmented by theoretical ideas from the cutback management literature and directly applies to educational administrators. Second, the article develops an empirical strategy about how to estimate the effects of fiscal reserves on government spending, broadly, and on U.S. school district spending, specifically. 
What follows is a conceptual framework that details a budget constraint and a review of the literature on school district stabilization. Then, the data and empirical approach is detailed. Model estimates are presented in the findings section. A conclusion considers implications for the literature and practitioners.

\section{Conceptual Framework}

\section{Budget Constraint}

The conceptual framework starts with an identity that is based on a government budget constraint and can be used and modified for different types and levels of governments worldwide:

(1) $\operatorname{Rev}_{i t}=$ Exp $_{i t}+$ UnassignedReserves $_{i t}+$ Other Reserves $_{i t}$

where $R e v_{i t}$ and $E x p_{i t}$ denote total revenues and expenditures of government $i$ during fiscal year $t$, respectively. Unassigned Reserves ${ }_{i t}$ measures all reserves that can be used on a discretionary basis, and Other Reserves it $_{\text {summarizes reserves funds }}$ that serve specific purposes, such as debt, investment, or capital reserve funds. In the next step, the difference is taken between the current and last year's value $\Delta_{t}$ for government $i$ and Equation (1) is rearranged to focus on expenditures on the left hand side of the equation, based on previous conceptualizations in analyses of fiscal reserves in school districts (e.g., Vanyolos, 2011):

(2) $\Delta_{t} \operatorname{Exp}_{i}=\Delta_{t} \operatorname{Rev}_{i}-\Delta_{t}$ UnassignedReserves $_{i}-\Delta_{t}$ Other Reserves $_{i}$

According to Equation (2), alterations in reserves are determined by variations in expenditures and the difference between changes in revenues and other reserve funds. Unassigned fiscal reserves are accumulated if: 1) expenditures decline at a lesser rate than the difference between revenues and other reserve funds; 2) expenditures stay the same 
or decrease and the disparity between revenues and other reserve funds increases; or 3) expenditures grow at a lesser rate than the gap between revenues and other reserve funds. The gain in savings is determined by the positive difference between alterations in expenditures and the difference of changes in revenues and other reserve funds.

Other fiscal reserves are drained if: 4) expenditures decrease at a lesser rate than the difference between revenues and other reserve funds; 5) expenditures increase and the difference between revenues and other reserve funds decreases or stays the same; or 6) the growth in expenditures is greater than the gap between revenues and other reserve funds. The impact of unassigned reserves on spending depends on the amount of money that is drained from these reserves. If the decrease in unassigned reserves equals the decline in the difference between revenues and other reserve funds, expenditure cutbacks are averted. It is important to note, however, that if unassigned reserves are drained less than increases in spending and revenues cannot be raised, governments need to cutback spending or decrease other reserve funds to stay financially viable. However, this can be difficult given the nature of other reserve funds spending being for other particular purposes $^{1}$.

\section{[Insert Table 1]}

The theoretical thoughts from above are summarized in Table 1. Which of these effects prevails is an empirical question with considerable relevance for governments around the world and their provision of public services, including education. The next section considers how the conceptual framework is related to the literature on cutback management (Levine, 1978, 1979).

\footnotetext{
${ }^{1}$ See, for example, Barrett et al. (2019) for further discussion of different types of reserves in school districts.
} 


\section{Stabilizing Public Education Expenditure Cuts}

The existing literature on how school districts accumulate reserves (propositions 1 to 3 in prior subsection) is sparse (Barrett et al., 2019; Duncombe and Hou, 2014; Hulpke and Watne, 1976; Kim and Ryu, 2017) ${ }^{2}$. The existing studies provide evidence that financial and socioeconomic characteristics, such as school district revenues, household income, and enrollment, are important factors influencing reserves accumulation. Barrett et al. (2019) and Duncombe and Hou (2014) further stress that school districts accumulate savings over the business cycle.

How fiscal reserves are drained in school districts (propositions 4 to 6 in prior subsection) to address events such as fiscal shocks has received much less attention. Most important for this study are the findings by Arapis et al. (2017), who reveal that Pennsylvania's school districts drained reserves while simultaneously cutting expenditures. Due to this novel finding and the call for further research on how school districts drain their fiscal reserves (Arapis et al. 2017; Barrett et al. 2019), this article draws on cutback management theory (Levine, 1978; 1979) to consider how governments may use fiscal reserves.

Cutback management is defined by Levine (1979) as "managing organizational change toward lower levels of resource consumption and organizational activity" (p. 180). When applied to education, cutback management can help to understand which strategies educator can choose when confronted with decreasing revenues (Arapis et al., 2017; Berne and Stiefel, 1993). Examining cutback decisions is critical since "responses of the moment can create long-term change, not just a temporary deviation" in public education expenditures (Berne and Stiefel, 1993, p. 682) which can have implications

\footnotetext{
${ }^{2}$ As confirmed by a recent comprehensive review of the literature on subnational fiscal reserves, including school districts, from Gorina et al. (2019).
} 
for student spending equity and student performance (Jackson, Wigger, and Xiong, 2018; Moulick and Taylor, 2017)

While expenditures can be cut, Levine $(1978 ; 1979)$ considers the use of fiscal reserves, which are also called slack resources ${ }^{3}$, to reduce or potentially avert cuts. Specifically, Levine (1978) argues that reserves can "minimize the perturbations of adjusting to new organizational equilibriums at successively lower levels of funding and activity" (p. 317). In relation to education, Arapis et al. (2017) recommend the use of reserves to mitigate budgetary pressures arising from revenue reductions. Whether educational administrators stabilize expenditures is the focus of the first research question: Do U.S. school districts use unassigned fiscal reserves to stabilize expenditure cuts?

A related question concerns the use of other fiscal reserves. Given evidence of other reserves for particular purposes that are accumulated by school districts, such as for capital costs (Reitano et al., 2019) ${ }^{4}$, school districts may also use other fiscal reserves for particular purposes. Since other reserves are for particular expenditures, they are distinct from unassigned reserves, which can be used on a discretionary basis. Whether school districts use other fiscal reserves for particular expenditure cutback stabilization purposes is unexamined in the literature. This yields the second research question: Do U.S. school districts use other fiscal reserves to stabilize expenditure cuts? Levine $(1978 ; 1979)$ also considers that total expenditures are composed of different expenditure categories when cutting back (Also see Behn, 1985). In relation to education, two general expenditure categories include instructional and non-

\footnotetext{
${ }^{3}$ See Barrett et al. (2019) for a discussion of how fiscal reserves are a form of slack resources in school districts.

${ }^{4}$ Reitano et al. (2019) show evidence that capital reserves are accumulated by Kentucky school districts, calling into question other types of reserves that might be accumulated. They do not, however, examine when these other reserves are drained and if this occurs in response to budgetary pressures.
} 
instructional (Sorensen, 2016). Instructional spending includes all expenditures related to classroom activities and are primarily composed of teacher salaries. Non-instructional expenditures include costs such as administration and facilities. Whether educational administrators stabilize particular expenditure categories with reserves is unknown ${ }^{5}$, but involves a critical concern regarding the type of cuts during cutback management (Raudla, Savi, and Randma-Liiv, 2015, p. 441). ${ }^{6}$ This yields the third research question: Do U.S. school districts use either unassigned fiscal reserves or other fiscal reserves to stabilize cuts to particular expenditure categories?

\section{Research Methodology}

This section starts with a discussion of the data. Variable operationalization is carefully considered. Then, in relation to the budget constraint from the previous section, this section details appropriate empirical models.

\section{Data}

The data for this study comes from different sources. Descriptive statistics for all variables are presented in Table 2. Financial information are taken from school district annual financial reports (AFRs) that are maintained and validated by the Kentucky Department of Education (DoE). Three dependent variables are created using this information. The first dependent variable tracks if districts engaged into expenditure cutback between the current and last school year. The second dependent variable measures the magnitude of those cutbacks by subtracting last year's from the current

\footnotetext{
${ }^{5}$ There are different theories about stakeholder conflicts over slack resources in firms (e.g., Bourgeois, 1981; Cyert and March, 1963; Kuusela et al., 2017; Su, 2018). Given differences in theoretical expectations in previous articles, and a lack of data on stakeholders in school districts, this article instead focuses on theory from Levine $(1978 ; 1979)$ on the distribution of cutbacks.

${ }^{6}$ Raudla et al. (2015, p. 442) state the following: "The fundamental question of cutback management is the contents of cutbacks: what should be cut."
} 
year's total spending. Positive changes, therefore, imply increases in district expenditures. A last set of dependent variables analyze different measures of spending categories including instruction, non-instruction ${ }^{7}$, and facilities.

Independent variables, based on school district's financial information, include total revenues and unassigned reserves, which we will henceforth call by its more technical term - unassigned fund balance (UFB). Changes in these measures are calculated in the same way as for expenditures. Thus, a positive change in revenues indicates growing district income and a positive change in the UFB implies that districts increased their reserves. Note that with respect to Equation (1), the category "Other Reserves" is excluded from the empirical analysis for reasons of collinearity. In this study, the category "Other Reserves" includes reserve funds for debt service, investments, and other capital outlays. Additionally, lagged expenditures are included in the models to overcome potential simultaneity bias between revenues and expenditures, but also UFB and expenditure measures (Wooldridge, 2010).

Similar to prior research (Gordon, 2004, 2008), the study controls for a wide range of student and school district characteristics, which are taken from data sets provided by the National Center for Education Statistics (NCES) and the U.S. Census, respectively. Student characteristics include total enrollment and the percentage shares of students that are white, eligible for free or reduced-price lunch (FRL), have limited English proficiency, and receive an individualized Education Plan (IEP)

Community variables consist of the percentage share of residents older than 65 , younger than 18, and having a bachelor degree. Further covariates include the percentage share of owner occupied housing, median housing values, and median

\footnotetext{
${ }^{7}$ Non-instructional expenses include: support, administrative, food, communication, enterprise, and business services, plant operation, transportation, food, adult education, and other spending.
} 
income for households. We linearly interpolate for missing values in these variables (Brunner and Schwegman, 2017). Moreover, the unemployment rate and the comparable wage index are added. The comparable wage index measures wages in professions that are comparable to teaching to control for regional differences. ${ }^{8}$

Taking all these variables together, the final data set ranges from school year (SY) 2001-2002 to SY 2013-2014 and includes 176 Kentucky school districts. The dataset cannot be updated with more recent data for the following reasons. ${ }^{9}$ First, more recent Kentucky school district fiscal reserves data aggregates unassigned reserves with committed and assigned reserves (Kentucky Department of Education, 2015a, 2015b). Thus, there is no way to disaggregate the reserves and isolate unassigned reserves, a key variable, past 2014. Second, KDE lags a few years in publishing AFR revenue and expenditure data because it must audit and verify the data ${ }^{10}$. Third, one of the covariates that controls for regional differences in teacher salary (CWI) was not available after SY 2013-14, so more recent years were not available for analysis. The panel still includes enough years to observe school district cutback behavior before, during, and after the Great Recession, which began in December $2007^{11}$. Further, enrollment was not consistently reported for three districts, so they were excluded from the analysis.

\section{Empirical Model}

Our empirical strategy consist of two models with distinct estimation procedures. The first model regresses the binary variable indicating if school districts

\footnotetext{
${ }^{8}$ The data was developed by NCES and can be downloaded for all years from Lori Taylor's webpage: https://bush.tamu.edu/research/faculty/Taylor_CWI/

${ }^{9}$ Gorina et al. (2019) note that "data on fiscal reserves are difficult to collect" (p. 1).

${ }^{10}$ States that do not have specified audit requirements for lower levels of government may allow "school districts to function outside of legal requirements and proper accounting procedures" (Carslaw, Mason, and Mills, 2007, p. 313). Thus, audited data has higher accuracy than unaudited data.

${ }^{11}$ Examining school district fiscal reserves data before, during, and after the Great Recession is consistent with Arapis et al. (2017).
} 
cutback expenses on changes in district finances and the control variables. More specifically, the following equation is estimated:

(3) Cutback $_{i t}=\beta_{0}+\beta_{1} \Delta U F B_{i t}+\beta_{2} \Delta \operatorname{Rev}_{i t}+\beta_{3}$ Controls $_{i t}+\alpha_{i}+\gamma_{t}+\varepsilon_{i t}$

where Cutback $_{i t}$ is a dichotomous variable that equals one in district $i$ during fiscal year $t$ if expenses were cutback and is zero otherwise. $\Delta U F B_{i t}$ and $\Delta R e v_{i t}$ are changes in unassigned reserves and total revenues, respectively. Controls $\boldsymbol{S}_{i t}$ is a vector of control variables described in the last section. District fixed effects, $\alpha_{i}$, control for all time-invariant school district characteristics, such as parent's interest in monitoring school officials, and year fixed effects, $\gamma_{t}$, control for all shocks that are common amongst the districts in our sample, such as, for instance, changes in gas prices for school buses.

Equation (3) is estimated using a linear probability model (LPM), allowing the inclusion of the above described fixed effects and giving the coefficients an interpretation as the linear probability of cutting back. Thus, negative coefficients imply a decreased and positive coefficients an increased probability of cutting back. To address potential heteroscedasticity, standard errors are clustered at the district level.

The second model utilizes the change in different expenditure measures as a dependent variable. Equation (4) is as follows:

$$
\text { (4) } \Delta \operatorname{Exp}_{i t}=\beta_{0}+\beta_{1} \Delta U F B_{i t}+\beta_{2} \Delta \operatorname{Rev}_{i t}+\beta_{3} \text { Controls }_{i t}+\alpha_{i}+\gamma_{t}+\varepsilon_{i t}
$$

where $\Delta E x p_{i t}$ measures changes in expenditures for different spending categories. The equation is estimated using OLS with fixed effects for districts and time. Standard errors are clustered at the district level. The coefficients in Equation 4 are interpreted as the impact of a one unit change in the independent variable on the dependent variable. Note the differences in the estimation technique and interpretation 
of coefficients between Equation 3 and 4 which are detailed further in the findings section which follows.

\section{Findings}

Table 3 shows the results for Equation 3 in Model 1, using a dependent variable that equals one if a district is cutting back expenditures and zero otherwise. As a LPM is used to estimate Equation 3, the coefficients indicate the percent change in the likelihood of a cutback for a one unit change in the covariate. With respect to the financial characteristics, changes in UFB, revenues, and lagged expenditures are all statistically significant. UFB and revenues were negatively related, and lagged expenditures were positively related. More specifically, a \$1 increase in the per-pupil UFB was associated with a 0.02 percent decrease in the probability of a cutback. Therefore, a school district that increased its UFB by one standard deviation (\$325.54) was 6.5 percent less likely to cut back on expenditures, keeping all other variables constant. A \$1 increase in per-pupil revenues was also associated with a 0.02 decrease in the probability of a cutback, so a school district with a per-pupil revenue increase of one standard deviation (\$772.79) was 15.5 percent less likely to cutback. Finally, a $\$ 1$ increase in last year's change in expenditures was associated with a 0.01 percent increase in the likelihood of a cutback.

Few other covariates were statistically significant in Model 1. An increase in enrollment was positively related to the likelihood of a cutback, and a one percent increase in the proportion of students identified as having limited English proficiency was associated with a 3.7 percent decrease in the likelihood of a cutback, though the standard errors around this estimate are very large. Additionally, school districts located in suburbs were 20.5 percent more likely to experience a cutback, compared to city school districts, though again, the standard errors are very large. 
Model 2 in Table 3 employs the change in total expenditure per pupil as dependent variable and provides estimates for Equation 4 using OLS with fixed effects. A $\$ 1$ increase in per-pupil UFB was associated with a $\$ 0.40$ increase in per-pupil expenditures, which suggest that school districts added to their UFBs as they were also increasing expenditures (or drew down UFBs as per-pupil expenditures fell).

As expected, a $\$ 1$ increase in per-pupil revenues was associated with a $\$ 0.75$ increase in per-pupil expenditures, and a \$1 decrease in last year's expenditures was associated with a $\$ 0.19$ decrease in this year's expenditures. Again, few other covariates were statistically significant. A one percent increase in the proportion of students identified as LEP was associated with a $\$ 115.28$ increase in per-pupil expenditures, though the standard errors around that were again large. A one percent increases in the proportion of owner occupied housing was associated a $\$ 54.02$ increase in per-pupil expenditures.

Thus far, results reflect a surprising relationship between changes in UFB and expenditures, which differ from previous findings (Arapis et al., 2017). Controlling for changes in revenues, school districts increased expenditures as they added to their UFB. These results prompt two questions. First, if school districts added to UFB and expenditures, where did the additional money come from if revenues had fallen? To answer this question, the first column of Table 4 presents predictive margins from the estimation of Equation 4 (Model 2). Changes in expenditures are estimated at values of $-\$ 100, \$ 0$, and $\$ 100$ for changes in revenues ${ }^{12}$ and UFBs. ${ }^{13}$, Given Equation 2 in the

\footnotetext{
${ }^{12}$ For changes in revenue, approximately a third of the district-year observations had a revenue decrease of $\$ 100$ or more, and half of the sample had a revenue increase of $\$ 100$. The remaining 15 percent were evenly split above and below $\$ 0$.

${ }^{13}$ Values of $-\$ 100, \$ 0,100$ were chosen for simplicity of reporting. For changes in UFB, approximately a third of the district-year observations in the sample had a change in UFB that was less than $-\$ 100$, and a third of the sample had a change of UFB that was greater than $\$ 100$. The remaining third of the sample was evenly split above and below $\$ 0$.
} 
conceptual part of the paper, the category "Other reserves" (mainly reserves for debt, investment, and other capital expenditures) can be calculated by subtracting the sum of the values for revenues and UFBs from expenditures ${ }^{14}$. The findings are displayed in Column 4 of Table 4.

The first three rows in Table 4 show what happens to spending and UFB when revenues decline. The results suggest that if the UFB decreases, spending also declines. In contrast, if the UFB increases or stays the same, expenditures grow as well. The money for the increase in UFB and spending is transferred from other reserves. The following three rows analyze the relationship between the fiscal variables in the case that revenues stay the same. The signs on the other fiscal variables are similar to the previous three rows, but the magnitudes measured for spending are either less negative or more positive. The last part of Table 4 depicts changes in the variables of interest if revenues increase. For the case that the UFB decreases, spending increases and so do other reserves. If the UFB stays the same or increases, expenditures increase, too, but other reserves decrease once more. The spending increase is much larger if the UFB is not drained.

The second question relates to which expenditure categories school districts increased (decreased) when they added to (drew down) their UFB. To address that question, Table 5 presents results for Equation 4, but decomposes total expenditure into spending for instruction, non-instruction, and facilities. For comparative purposes Model 1 shows again the results for changes in total expenditures. The coefficients are once more estimated using OLS with fixed effects and show the impact of a one unit change in the independent on the dependent variable. The UFB variable is imprecisely

\footnotetext{
${ }^{14}$ The first row in Table 4 is calculated: $-49-(-100-(-100))=-\Delta$ Other Reserves; 49
} 
estimated for Model 2 and the sign on the coefficient is contrary to Model 1. A \$1 increase in per-pupil UFB is associated with a $\$ 0.10$ decrease in per-pupil noninstructional expenditures. The coefficients on the UFB variable for the two remaining models are statistically significant. With a $\$ 1$ increase in the UFB, non-instructional expenditures are cut by 10 cents and facility spending is increased by 53 cents.

\section{Conclusion}

This study developed a conceptual framework to analyze monetary transfers in and out of a government's fiscal reserves. The findings of the empirical analysis, which used school districts in the United States as an example, showed a nuanced story about expenditure stabilization with fiscal reserves. There are four key findings with implications for the literature and practitioners.

First, this study provides evidence that when school districts face declining revenues, they utilize their unassigned reserves to stabilize their budget, while also cutting expenditures. In particular, the analysis shows that for every $\$ 1$ per pupil that is withdrawn from the unassigned reserves, 50 cents are used to reduce cutbacks in spending. The remaining 50 cents are transferred in other reserves, which mainly consist of capital and facility related outlays. This finding clearly shows the stabilization function of unassigned reserves, not only for expenditures.

Second, the results suggest that school districts withdraw money from their other reserves and use these resources for budget stabilization. Specifically, the results establish that other reserves play a major role in budget stabilization, which has not been discussed in the prior literature. In cases when revenues decline by $\$ 100$ per pupil, transfers from the other funds help to increase spending and unassigned savings by about $\$ 100$ each. Thus, these reserves are not only used for stabilizing spending but also to grow unassigned savings that can be easily accessed in future fiscal years. 
Third, there is an interplay between unassigned and other reserves, showing that both funds help sustaining each other. The interplay between unassigned and other reserves is also of great importance for school districts budgets, another finding that is new to the literature on the use of government savings, and can inform practitioners. When money is drawn from one source of savings, not only is spending stabilized but also the other reserve fund are increased, as well. This research cannot establish what the motivation behind these transfers is, but clearly shows that these transfers play an important role in budget stabilization.

Finally, unassigned reserves are mainly used to stabilize spending for facilities. The results for expenditure categories provided evidence that school districts do not use their unassigned savings for student related activities, but for maintaining operation and securing payments for fixed cost that arise in the short and long term and cannot be decreased. This finding is somewhat contrary to recommendations by the World Bank (2017 p. 5) to cut "capital and non-salary, recurring spending" first, when governments are faced with "budgetary constraints". No matter for which reasons school districts decide to maintain facility spending with unassigned savings, this study showed that the decision the use reserves is unlikely to stabilize all spending categories in a government budget.

From a managerial perspective, school districts should consider greater transparency around the use of fiscal reserves (Stewart, Hildreth, Antwi-Boaskiako, 2015). For instance, school districts could release information not only about their fiscal reserves accumulation strategy, but also how they drain these funds and for what purpose. Another recommendation, related to the findings in this study, is that school districts should consider adopting financial policies around reserves accumulation and usage (Kavanagh, 2012). These financial policies could specify target levels for reserves and a 
strategy for when to drain them and for "appropriate uses" (Government Finance Officers Association, 2017, p. 10).

From a policy perspective, state education departments could encourage districts to increase their financial transparency and adopt institutional rules for reserves. Further, state education departments could implement fiscal monitoring systems to measure changes in fiscal variables over time, including fiscal reserves (Bruck and Miltenberger, 2013). These systems can help states to monitor for early warning signs and potentially implement corrective actions before school districts slide into fiscal stress (Coe, 2008; Kloha, Weissert, and Kleine, 2005).

Future research can apply the conceptual framework and empirical approach developed in this article in the U.S. context and modify it for research in non-U.S. contexts. What remains to be seen is how other types of stabilization arrangements, beyond fiscal reserves in the U.S., may be used in a comparative sense (Rubin, 2015). Further, more qualitative research can provide insight into how these decisions are being made, whether from budget and finance officers, superintendents, or other public administrators (e.g., Kavanagh, 2007; Rubin, 2015). Clearly, there are considerable opportunities to understand how educational administrators stabilize expenditures when faced with budgetary pressures, a research question that has global relevance (World Bank, 2017). 


\section{References}

Arapis, T., \& Reitano, V. (2018). A glimmer of optimism in government savings accumulation? An empirical examination of municipal unassigned fund balance in Florida." Public Finance Review, 46(3), 389-420.

Arapis, T., Reitano, V., \& Bruck, E. (2017). The fiscal savings behavior of Pennsylvania school districts through the great recession. Public Budgeting \& Finance, 37(3), 47-70.

Barrett, N., Fowles, J., Jones, P., \& Reitano, V. (2019). Forecast bias and fiscal slack accumulation in school districts. American Review of Public Administration, 49(5), 601-613.

Behn, Robert. (1985). Cutback budgeting. Journal of Policy Analysis and Management, 4(2), 155-177.

Berne, Robert and Leanna Stiefel. (1993). Cutback budgeting: The long-term consequences. Journal of Policy Analysis and Management, 12(4), 664-684.

Bourgeois, L.J. (1981). On the measurement of organizational slack. The Academy of Management Review, 6(1), 29-39.

Bruck, W.E., \& Miltenberger, L. (2013). A school district financial condition assessment system and its application to Pennsylvania school districts. Journal of Education Finance, 39(2), 115-131.

Brunner, E., \& Schwegman, D. (2017). The impact of Georgia's education special purpose local option sales tax on the fiscal behavior of local school districts. National Tax Journal, 70(2), 295-328.

Carslaw, C., Mason, R., \& Mills, J. (2007). Audit timeliness of school district audits. Journal of Public Budgeting, Accounting \& Financial Management, 19(3), 290316.

Coe, C. (2008). Preventing local government fiscal crises: Emerging best practices. Public Administration Review, 68(4), 759-767.

Cyert, Richard and James March. (1963). A behavioral theory of the firm. Englewood Cliffs, NJ: Prentice Hall.

Duncombe, B. \& Hou, Y. (2014). The savings behavior of special purpose governments: A panel study of New York school districts. Public Budgeting \& Finance, 34(3), 1-23.

Gordon, N. (2004). Do federal grants boost school spending? Evidence from title I. Journal of Public Economics, 88(9-10), 1771-1792.

Gordon, N. (2008). The changing federal role in education finance and governance. In H.F. Ladd \& E.B. Fiske (Eds.), Handbook of research in education finance and policy (pp. 295-313). Routledge.

Gorina, E., Maher, C., \& Park, S. (2019). Toward a theory of fiscal slack. Public Budgeting \& Finance, 39(4), 1-27.

Government Finance Officers Association. (2017). Best practices in school budgeting. Chicago, IL: GFOA.

Hulpke, J.F., \& Watne, D.A. (1976). Budgeting behavior: If, when, and how selected school districts hide money. Public Administration Review, 36(6), 667-674.

Jackson, K., Wigger, C., \& Xiong, H. (2018). Do school spending cuts matter? Evidence from the great recession. NBER Working Paper 24203. Cambridge, MA: NBER.

Kavanagh, Shayne. (2007). Financing the future: Long-term financial planning for local government. Chicago, IL: Government Finance Officers Association. 
Kavanagh, Shayne. (2012). Financial policies. Chicago, IL: Government Finance Officers Association.

Kentucky Department of Education. (2015a). GASB 54 best practices \& FAQ.

Retrieved from

https://education.ky.gov/districts/FinRept/Pages/Fund\%20Balances, \%20Revenu es $\% 20$ and $\% 20$ Expenditures, $\% 20$ Chart $\% 20$ of $\% 20$ Accounts, $\% 20$ Indirect $\% 20 \mathrm{CoS}$ t $\% 20$ Rates $\% 20$ and $\% 20$ Key\%20Financial $\% 20$ Indicators.aspx

Kentucky Department of Education. (2015b). Fund balance 2015-2016 unaudited.

Retrieved from

https://education.ky.gov/districts/FinRept/Pages/Fund\%20Balances, \%20Revenu es $\% 20$ and $\% 20$ Expenditures, $\% 20$ Chart $\% 20$ of $\% 20$ Accounts, $\% 20$ Indirect $\% 20 \mathrm{Cos}$ t\%20Rates $\% 20$ and $\% 20$ Key $\% 20$ Financial $\% 20$ Indicators.aspx

Kentucky Department of Education. (2020). KDE chart of accounts quick reference Guide FY2019-2020. Retrieved from

https://education.ky.gov/districts/FinRept/Pages/Fund\%20Balances, \%20Revenu es \%20and $\% 20$ Expenditures, $\% 20$ Chart $\% 20$ of $\% 20$ Accounts, $\% 20$ Indirect $\% 20$ Cos t $\% 20$ Rates $\% 20$ and $\% 20$ Key $\% 20$ Financial $\% 20$ Indicators.aspx

Kim, S., \& Ryu, S. (2017). Strategic public management for financial condition: Focus on fund balances of school districts. The Social Science Journal, 54, 249-260.

Kloha, P., Weissert, C.S., \& Kleine, R. (2005). Someone to watch over me: State monitoring of local fiscal conditions. American Review of Public Administration, 35(3), 236-255.

Kuusela, P., Keil, T., \& Maula, M. (2017). Driven by aspirations, but in what direction? Performance shortfalls, slack resources, and resource-consuming vs. resourcefreeing organizational change. Strategic Management Journal, 38, 1101-1120.

Levine, C.H. (1978). Organizational decline and cutback management. Public Administration Review, 38(4), 316-25.

Levine, C.H. (1979). More on cutback management: Hard questions for hard times. Public Administration Review, 39(2), 179-83.

Moulick, A.G., \& Taylor, L.L. (2017). Fiscal slack, budget shocks, and performance in public organizations: Evidence from public schools. Public Management Review, 19(7), 990-1005.

Nelson, A., \& Balu, R. (2014). Local government response to fiscal stress: Evidence from the public education sector. Public Administration Review, 74(5), 601-614.

Raudla, R., Riin, S., \& Randma-Liiv, T. (2015). Cutback management literature in the 1970s and 1980s: Taking stock. International Review of Administrative Sciences, 81(3), 433-456.

Reitano, V., Jones, P., Barrett, N., \& Fowles, J. (2019). "Forecast Bias and Capital Reserves Accumulation." In D. Williams \& C. Calabrese (Eds.), The Palgrave Handbook of Government Budget Forecasting, Palgrave Macmillan.

Rubin, I. (2015). Past and future budget classics: A research agenda. Public Administration Review, 75(1), 25-35.

Sorensen, L. (2016). Outside the classroom: Evidence on non-instructional spending and student outcomes. Paper presented at the AEFP $41^{\text {st }}$ Annual Conference.

Stewart, L.M., Hildreth, R.W., \& Antwi-Boasiako, K.B. (2015). The fund balance conundrum: An ethical perspective. Administration \& Society, 47(8), 915-942.

$\mathrm{Su}$, M. (2018). Understanding the accumulation of local government savings: A dynamic analysis. International Journal of Public Administration, 42(11), 893903. 
Su, M. (2019). Local governments' response to revenue changes: The effects of unreserved general fund balances. International Journal of Public Administration.

Wooldridge, J. (2010). Econometric analysis of cross section and panel data. MIT Press.

World Bank. (2017). Education public expenditure review guidelines. Washington, DC: World Bank.

Vanyolos, I. (2011). The impact of state-imposed fund balance limits on school districts: Evidence from New York state. Journal of Public Budgeting, Accounting \& Financial Management, 23(2), 166-187. 
Table 1: The relationship between changes in revenues, expenditures, unassigned reserves, and other reserves

\begin{tabular}{|c|c|c|}
\hline & \multicolumn{2}{|c|}{$\Delta_{t} \boldsymbol{R e v}_{i}-\Delta_{t}$ Other Reserves ${ }_{i}$} \\
\hline & negative & Positive \\
\hline negative & $\begin{array}{l}\text { 1) unassigned reserves are accumulated if the } \\
\text { decline in expenditure is greater than the } \\
\text { difference in revenues and other reserve funds } \\
\text { 4) unassigned reserves are drained if the } \\
\text { decline in expenditures is revenues is smaller } \\
\text { than in expenditures and other reserve funds }\end{array}$ & 2) unassigned reserves are accumulated \\
\hline$\Delta_{t} \operatorname{Exp}_{i}$ & 5) unassigned reserves are drained & $\begin{array}{l}\text { 3) unassigned reserves are accumulated if the } \\
\text { growth in expenditures is less than the } \\
\text { difference between revenues and other reserve } \\
\text { funds }\end{array}$ \\
\hline Positive & & $\begin{array}{l}\text { 6) unassigned reserves are drained if the } \\
\text { growth in expenditures is greater than the } \\
\text { difference between revenues and other reserve } \\
\text { funds }\end{array}$ \\
\hline
\end{tabular}


Table 2: Descriptive statistics

\begin{tabular}{|c|c|c|c|c|c|}
\hline 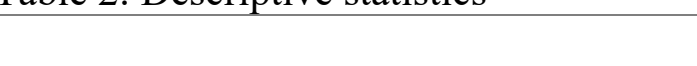 & Mean & Std. Dev. & Min & Median & Max \\
\hline \multicolumn{6}{|l|}{ District financial characteristics } \\
\hline Expenditures & $\$ 12,385.23$ & $\$ 1,998.86$ & $\$ 7,827.18$ & $\$ 11,967.47$ & $\$ 23,686.07$ \\
\hline$\Delta$ Expenditures & $\$ 147.25$ & $\$ 1,735.76$ & $-\$ 9,054.65$ & $\$ 95.78$ & $\$ 9,702.46$ \\
\hline \multicolumn{6}{|l|}{ Expenditure categories } \\
\hline Instructional expenditures & $\$ 4,411.08$ & $\$ 670.88$ & $\$ 2,670.46$ & $\$ 4,336.17$ & $\$ 7,983.13$ \\
\hline$\Delta$ Instructional expenditures & $-\$ 95.11$ & $\$ 317.10$ & $-\$ 2,179.82$ & $-\$ 102.04$ & $\$ 2,015.33$ \\
\hline Non-instructional expenditures & $\$ 3,355.34$ & $\$ 575.21$ & $\$ 2,060.24$ & $\$ 3,275.55$ & $\$ 7,542.34$ \\
\hline$\Delta$ Non-instructional expenditures & $-\$ 38.22$ & $\$ 257.44$ & $-\$ 1,809.71$ & $-\$ 42.03$ & $\$ 1,376.71$ \\
\hline Facility expenditures & $\$ 4,618.82$ & $\$ 1,708.94$ & $\$ 742.57$ & $\$ 4,303.30$ & $\$ 14,792.31$ \\
\hline$\Delta$ Facility expenditures & $\$ 280.58$ & $\$ 1,704.83$ & $-\$ 9,594.78$ & $\$ 270.45$ & $\$ 8,880.09$ \\
\hline UFB & $\$ 1,086.49$ & $\$ 743.32$ & $-\$ 471.22$ & $\$ 905.98$ & $\$ 5,597.24$ \\
\hline$\Delta \mathrm{UFB}$ & $-\$ 5.62$ & $\$ 325.54$ & $-\$ 1,808.09$ & $-\$ 4.34$ & $\$ 2,910.58$ \\
\hline Rev & $\$ 12,050.42$ & $\$ 1,488.24$ & $\$ 8,453.28$ & $\$ 11,820.12$ & $\$ 23,969.20$ \\
\hline$\Delta \operatorname{Rev}$ & $\$ 100.14$ & $\$ 772.79$ & $-\$ 6,760.72$ & $\$ 74.83$ & $\$ 6,090.15$ \\
\hline Federal funds $(\%)$ & 13.46 & 4.65 & 1.42 & 13.05 & 37.32 \\
\hline \multicolumn{6}{|l|}{ Student characteristics } \\
\hline Total enrollment & 3,903 & 8,186 & 123 & 2,386 & 100,529 \\
\hline White $(\%)$ & 90.49 & 11.23 & 35.89 & 94.83 & 100.00 \\
\hline FRL $(\%)$ & 58.41 & 15.72 & 0.08 & 58.82 & 98.97 \\
\hline LEP $(\%)$ & 0.99 & 1.76 & 0.00 & 0.34 & 14.20 \\
\hline $\operatorname{IEP}(\%)$ & 16.62 & 3.77 & 7.29 & 16.28 & 41.25 \\
\hline \multicolumn{6}{|l|}{ Community characteristics } \\
\hline Over $65(\%)$ & 14.36 & 2.89 & 0.00 & 14.23 & 24.70 \\
\hline Under $18(\%)$ & 23.62 & 2.54 & 9.35 & 23.70 & 36.48 \\
\hline
\end{tabular}




\begin{tabular}{lrrrrr}
\hline Bachelor's (\%) & 12.09 & 8.81 & 1.26 & 9.76 & 85.76 \\
Owner occupied house (\%) & 71.08 & 10.87 & 37.73 & 74.60 & 100.00 \\
Median home value (1,000s \$) & $\$ 142.08$ & $\$ 76.53$ & $\$ 55.65$ & $\$ 127.93$ & $\$ 911.54$ \\
Median HH income (1,000s \$) & $\$ 46.60$ & $\$ 11.52$ & $\$ 23.64$ & $\$ 46.21$ & $\$ 103.87$ \\
ECWI & 1.15 & 0.16 & 0.87 & 1.13 & 1.53 \\
Unemployment rate (\%) & 8.16 & 2.50 & 3.80 & 7.70 & 19.60 \\
\hline
\end{tabular}

Note: All dollars amounts are reported as per-pupil measures and in 2014 dollars. 
Table 3: Regression estimates considering probability and magnitude of cutback in per-pupil expenditures

\begin{tabular}{|c|c|c|}
\hline VARIABLES & $\begin{array}{c}\text { Prob Cutback } \\
\text { (Std. Err.) } \\
\text { (1) } \\
\end{array}$ & $\begin{array}{c}\Delta \operatorname{Exp}(p p) \\
(\text { Std. Error) } \\
(2)\end{array}$ \\
\hline$\Delta \mathrm{UFB}(\mathrm{pp})$ & $\begin{array}{c}-0.0002 * * * \\
(<0.0001)\end{array}$ & $\begin{array}{c}0.401 * * * \\
(0.127)\end{array}$ \\
\hline$\Delta \operatorname{Rev}(\mathrm{pp})$ & $\begin{array}{c}-0.0002 * * * \\
(<0.0001)\end{array}$ & $\begin{array}{c}0.754 * * * \\
(0.072)\end{array}$ \\
\hline Lagged $\Delta \operatorname{Exp}(p p)$ & $\begin{array}{c}<0.0001 * * * \\
(<0.0001)\end{array}$ & $\begin{array}{c}-0.193 * * * \\
(0.025)\end{array}$ \\
\hline Fed Rev (\%) & $\begin{array}{l}-0.0095 \\
(0.0081)\end{array}$ & $\begin{array}{c}24.541 \\
(23.759)\end{array}$ \\
\hline Enrollment & $\begin{array}{l}0.0001 * * \\
(<0.0001)\end{array}$ & $\begin{array}{l}-0.119 \\
(0.088)\end{array}$ \\
\hline White (\%) & $\begin{array}{l}-0.0049 \\
(0.0063)\end{array}$ & $\begin{array}{c}23.849 \\
(17.655)\end{array}$ \\
\hline FRL (\%) & $\begin{array}{c}0.0022 \\
(0.0022)\end{array}$ & $\begin{array}{l}-7.124 \\
(9.004)\end{array}$ \\
\hline LEP $(\%)$ & $\begin{array}{l}-0.0373 * \\
(0.0216)\end{array}$ & $\begin{array}{l}115.276^{*} \\
(65.271)\end{array}$ \\
\hline $\operatorname{IEP}(\%)$ & $\begin{array}{l}-0.0011 \\
(0.0064)\end{array}$ & $\begin{array}{l}45.141^{*} \\
(25.417)\end{array}$ \\
\hline Pop over $65(\%)$ & $\begin{array}{c}0.0028 \\
(0.0188)\end{array}$ & $\begin{array}{l}-24.318 \\
(37.617)\end{array}$ \\
\hline Pop under $18(\%)$ & $\begin{array}{c}0.0012 \\
(0.0161)\end{array}$ & $\begin{array}{c}28.356 \\
(39.053)\end{array}$ \\
\hline Pop w/ bachelors (\%) & $\begin{array}{l}-0.0035 \\
(0.0068)\end{array}$ & $\begin{array}{c}0.612 \\
(18.171)\end{array}$ \\
\hline Owner occupied housing $(\%)$ & $\begin{array}{l}-0.0091 \\
(0.0074)\end{array}$ & $\begin{array}{c}54.019 * * * \\
(18.338)\end{array}$ \\
\hline Median home value $(1,000$ s $\$)$ & $\begin{array}{c}0.0002 \\
(0.0017)\end{array}$ & $\begin{array}{c}5.236 \\
(4.099)\end{array}$ \\
\hline Median HH income $(1,000$ s $\$)$ & $\begin{array}{l}-0.0007 \\
(0.0054)\end{array}$ & $\begin{array}{c}-9.610 \\
(20.523)\end{array}$ \\
\hline Comparable wage index & $\begin{array}{l}-1.4396 \\
(0.9210)\end{array}$ & $\begin{array}{c}910.339 \\
(2,364.472)\end{array}$ \\
\hline Unemployment rate & $\begin{array}{c}0.0185 \\
(0.0124)\end{array}$ & $\begin{array}{c}-33.934 \\
(40.369)\end{array}$ \\
\hline Compared to city & & \\
\hline Suburb & $\begin{array}{l}0.2052 * \\
(0.1174)\end{array}$ & $\begin{array}{c}-507.817 \\
(357.642)\end{array}$ \\
\hline Town & 0.0724 & -423.933 \\
\hline
\end{tabular}




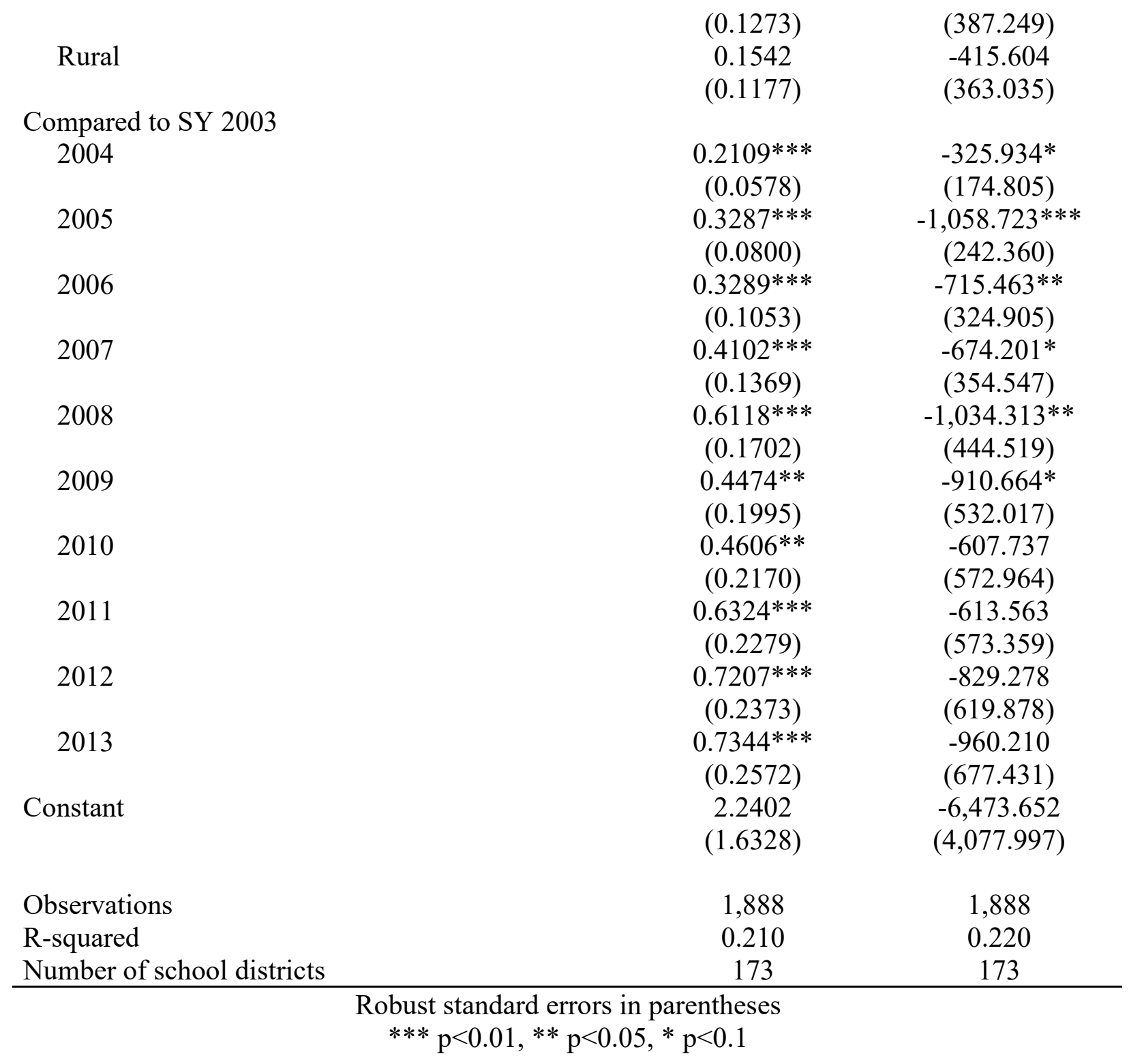


Table 4: Predictive margins for changes in per-pupil expenditures

\begin{tabular}{ccccc}
\hline $\begin{array}{c}\Delta \mathbf{E x p} \\
\mathbf{( 1 )}\end{array}$ & $\begin{array}{c}\Delta \mathbf{R e v} \\
\mathbf{( 2 )}\end{array}$ & $\begin{array}{c}\Delta \mathbf{U F B} \\
\mathbf{( 3 )}\end{array}$ & $\begin{array}{c}\Delta \text { Other Reserves } \\
\mathbf{( 4 )}\end{array}$ \\
\hline-49 & $* *$ & -100 & -100 & 49 \\
28 & $* *$ & -100 & 0 & -128 \\
106 & $* * *$ & -100 & 100 & -306 \\
-7 & & 0 & -100 & 107 \\
70 & $* * *$ & 0 & 0 & -70 \\
147 & $* * *$ & 0 & 100 & -247 \\
34 & & 100 & -100 & 166 \\
112 & $* * *$ & 100 & 0 & -12 \\
189 & $* * *$ & 100 & 100 & -189 \\
\hline
\end{tabular}


Table 5: Regression estimates considering magnitude of cutback in per-pupil instruction, non-instruction, and facilities expenditures

\begin{tabular}{|c|c|c|c|c|}
\hline VARIABLES & $\begin{array}{c}\Delta \operatorname{Exp}(\mathrm{pp}) \\
(\text { Std. Error) } \\
(1) \\
\end{array}$ & $\begin{array}{c}\Delta \text { Instruct Exp (pp) } \\
\text { (Std. Error) } \\
(2) \\
\end{array}$ & $\begin{array}{c}\Delta \text { Non-instruct Exp (pp) } \\
\text { (Std. Error) } \\
(3) \\
\end{array}$ & $\begin{array}{c}\Delta \text { Facilities Exp (pp) } \\
\text { (Std. Error) } \\
(4) \\
\end{array}$ \\
\hline$\Delta \mathrm{UFB}(\mathrm{pp})$ & $\begin{array}{c}0.401 * * * \\
(0.127)\end{array}$ & $\begin{array}{l}-0.043 \\
(0.034)\end{array}$ & $\begin{array}{c}-0.100 * * * \\
(0.022)\end{array}$ & $\begin{array}{c}0.526 * * * \\
(0.134)\end{array}$ \\
\hline$\Delta \operatorname{Rev}(\mathrm{pp})$ & $\begin{array}{c}0.754 * * * \\
(0.072)\end{array}$ & $\begin{array}{c}0.094 * * * \\
(0.020)\end{array}$ & $\begin{array}{c}0.054 * * * \\
(0.014)\end{array}$ & $\begin{array}{c}0.597 * * * \\
(0.081)\end{array}$ \\
\hline Lagged $\Delta \operatorname{Exp}(p p)$ & $\begin{array}{c}-0.193 * * * \\
(0.025)\end{array}$ & $\begin{array}{c}-0.222 * * * \\
(0.034)\end{array}$ & $\begin{array}{c}-0.314 * * * \\
(0.026)\end{array}$ & $\begin{array}{c}-0.214 * * * \\
(0.023)\end{array}$ \\
\hline Constant & $\begin{array}{l}-6,473.652 \\
(4,077.997)\end{array}$ & $\begin{array}{c}-1,845.085^{* *} \\
(900.850)\end{array}$ & $\begin{array}{l}-831.875 \\
(636.664)\end{array}$ & $\begin{array}{l}-4,068.240 \\
(4,156.933)\end{array}$ \\
\hline $\begin{array}{l}\text { Observations } \\
\text { R-squared } \\
\text { Number of school districts }\end{array}$ & $\begin{array}{c}1,888 \\
0.220 \\
173\end{array}$ & $\begin{array}{c}1,888 \\
0.393 \\
173\end{array}$ & $\begin{array}{c}1,888 \\
0.293 \\
173\end{array}$ & $\begin{array}{c}1,888 \\
0.171 \\
173\end{array}$ \\
\hline
\end{tabular}

